\title{
ANALISIS MAKNA LEKSIS SINGKOWOTON MENGGUNAKAN PENDEKATAN SEMANTIK RANAH BERSUMBERKAN DATA KORPUS BAHASA MELAYU
}

(THE ANALYSIS ON THE MEANING OF SINGKOWOTON VIA THE USAGE OF FRAME SEMANTICS APPROACH WITHIN THE MALAY LANGUAGE (ORPUS DATA)

\author{
Effendy Yusuff, Anida Sarudin, Norliza Jamaluddin \\ ffendyyusuff@yahoo.com.my, anida@fbk.upsi.edu.my, \\ norliza@fbk.upsi.edu.my \\ Fakulti Bahasa Melayu \\ Universiti Pendidikan Sultan Idris
}

\begin{abstract}
Abstrak
Penyelidikan ini dilaksanakan untuk mengkaji pengekalan penggunaan leksis bahasa sukuan peribumi Sabah dalam korpus bahasa Melayu. Sumber data yang dimanfaatkan adalah daripada data korpus bahasa Melayu yang dibangunkan sendiri oleh penyelidik dengan menggunakan Perisian Antconc 3.4.3w. Data korpus tersebut terdiri daripada enam buah novel berbahasa Melayu yang berlatarkan masyarakat peribumi Sabah. Sebanyak 145 leksis bahasa sukuan telah dikenal pasti dan digunakan secara bersama-sama dengan bahasa Melayu dalam data korpus. Bagaimanapun, dalam kertas kerja ini, salah satu leksis singkowoton dipilih untuk dianalisis. Analisis dijalankan dengan menggunakan teori semantik ranah (frame semantics) yang dipelopori oleh Charles Fillmore (1982). Dapatan kajian awal menunjukkan bahawa pendekatan berteori linguistik,
\end{abstract}


khususnya semantik kognitif dapat memerihalkan gelagat semantik leksis bahasa sukuan dalam korpus bahasa Melayu dan seterusnya menyelongkar makna yang cuba digambarkan untuk membawa konsep masyarakat penutur di sebalik penggunaan leksis tersebut. Hujahan yang dilakukan dapat menjelaskan fungsi kewujudan dan kewajaran setiap leksis adalah disebabkan motivasi, potensi dan reputasi leksis tersebut.

Kata kunci: leksis, bahasa sukuan, singkowoton, semantik ranah.

\section{Abstract}

This research explores the preservation of lexis used in the tribal languages of Sabah in the corpus of the Malay language. The data collected originate from the Malay language corpus, which was developed by the researcher by using Antconc 3.4.3w. The corpus was developed based on six Malay-language novels with narratives based on Sabah tribes. Of 145 lexis of the tribal language identified alongside the Malay language in the corpus data, one of the lexis, singkowoton, was chosen for analysis. The analysis was conducted with reference to the frame semantics coined by Charles Fillmore (1982). The initial results of the study show that the linguistics theoretical approach, specifically the semantic cognitive approach, observes the use of lexis semantic of the tribal languages within the corpus of the Malay language. In addition, the results inform the tribal understanding behind the usage of the lexis, as well as the motivation, potential and reputation regarding usage of the lexis.

Keywords: lexis, tribal language, singkowoton, frame semantic.

\section{Pengenalan}

Ketamadunan suatu bangsa terbina hasil proses minda manusia dalam membuat tanggapan ke atas alam, usaha mentakrif dirinya, dan membentuk pandangan hidup sehingga mengangkat tahap keintelektualan penciptanya. Pemikiran atau pandangan dunia sesuatu kelompok bangsa itu ditentukan oleh bahasanya (Sapir, 1921). Slobin (1996) menjelaskan bahawa penutur membina pemahaman dalam minda berdasarkan kejadian atau peristiwa yang dilihat di sekeliling, yang kemudian akan diungkap dalam bentuk butir-butir bahasa. Hal ini 
akhirnya akan membentuk gabungan ketiga-tiga elemen iaitu masyarakat, bahasa dan budaya.

Zainal Kling (1993) menjelaskan bahawa pemikiran ialah operasi membentuk sistem tanggapan untuk membentuk rangka berfikir anggota masyarakat. Mekanisme yang terlibat ini berbentuk satu sistem yang begitu kompleks yang mengandungi pola-pola dan peraturan tertentu. $\mathrm{Hal}$ ini bererti pandangan terhadap alam mengandungi elemen ketinggian akal kerana telah berlaku analisis, tafsiran, penilaian dan rumusan sebelum mengambil keputusan untuk mengangkat sesuatu perkara, benda dan konsep sebagai pegangan dalam kehidupan. Proses ini begitu rencam kerana melibatkan benda yang abstrak yang bermain dalam minda penutur. Hal ini ditambah lagi sifat pandangan ke atas alam sekeliling itu harus diselimuti oleh nilai-nilai budaya, pegangan hidup, kesamaan dan kebolehterimaan penuturnya. Konsep-konsep dalam akal budi dan ketamadunan bangsa banyak diterjemahkan menerusi penggunaan bahasa sama ada berbentuk lisan atau pun dokumentasi. Bahasa diakui sebagai wadah komunikasi yang terbaik dalam mencitrakan budaya dan pemikiran suatu masyarakat hasil interpretasi terhadap alam sekeliling yang dikenali sebagai worldview (Mohd Taib 1988, Sutan Takdir Alisyabana 1990, LeviStauss 1993, Saidatul Nornis 2007). Bahasa bukan sekadar berfungsi sebagai alat komunikasi antara anggota masyarakat, malah menjadi ciri yang mendefinisi bangsa.

Sapir (1984) dan Whorf (1956) menjelaskan penggunaan bahasa yang berbeza-beza memberikan pengalaman realiti yang berlainan kepada penutur disebabkan oleh perbendaharaan kata serta hukum nahu menentukan bagaimana pengguna bahasa itu harus memahami dunianya. Hal ini bermakna bahawa setiap masyarakat melihat dunia dari sudut pandangan masing-masing. Pandangan yang terbina secara kolektif, akhirnya membentuk pemikiran yang sejagat yang kebiasaannya mewakili identiti suatu kelompok masyarakat. Oleh yang demikian, sesuatu kelompok masyarakat atau penutur yang sama memiliki persamaan dalam mentafsir dunia mereka. Kebersamaan ini menguatkan lagi tanggapan bahawa cara pemikiran yang dipunyai oleh penutur itu bersifat sejagat. Ketinggian akal budi ini pula dikongsi bersama-sama dalam melayari kehidupan. Hal ini menunjukkan bahawa sememangnya wujud satu 
sistem yang mengawal cara atau sifat pemikiran itu. Hal ini juga bererti suatu pemikiran itu sebenarnya mempunyai sistem yang kompleks dan pola-pola tertentu yang abstrak sifatnya.

Ketepatan takrif makna sesuatu kata berhubung kait dengan kebudayaan sesuatu masyarakat. Hal ini terjadi kerana bahasa itu bukan sahaja merupakan hasil budaya, bahkan merupakan medium penyampai kebudayaan masyarakat berkenaan. Unsur budaya pula perlu diterjemahkan dan dianalisis untuk menggambarkan realiti penuturnya (Aini Abd Karim, 2005). Justeru, di sinilah peranan ilmu linguistik yakni kajian tentang makna dapat membantu penyelidikan perihal aspek bahasa khususnya leksikal yang bertindak sebagai perakam yang bernilai. Berlandaskan itu, ilmu semantik ialah pendekatan yang paling relevan untuk menghuraikan perilaku tersebut. Hal ini disebabkan oleh teori semantik ialah salah satu cabang linguistik yang berhubung erat dengan bidang sosiologi, antropologi, falsafah dan psikologi (Saidatul Nornis, 2007) yang dilihat berupaya menjelaskan dan memperinci operasi pengatucaraan yang berlaku. Dalam bidang semantik kognitif, elemen pengalaman (experientalist approach) iaitu pengalaman lampau dan alam sekeliling diambil kira. Makna yang dikonsepsikan berlandaskan struktur yang lazim (conventionalized conceptual structure) ialah kerangka utama teori ini. Dengan kata lain, melalui ilmu semantik kognitif. pengalaman dan pergaulan penutur yang telah sedia ada dalam mental dapat dimanifestasikan.

Dalam pada itu, Puteri Roslina (2012) menjelaskan bahawa setiap bahasa di dunia mempunyai khazanah perbendaharaan kata yang terbentuk berdasarkan keperluan persekitaran dan budaya mereka. Kadangkala berlaku ketidakcukupan kata dalam sesuatu bahasa untuk mengungkapkan konsep tertentu yang tidak pernah wujud dalam bahasa tersebut. Oleh itu, peminjaman kata merupakan sumber dalam kajian kosa kata. Dalam hal ini, berdasarkan data korpus yang diselidiki, beberapa leksikal bahasa kedua didapati telah digunakan secara bersamasama dalam bahasa pertama. Hal ini amat menarik untuk diteliti dengan lebih mendalam untuk melihat bagaimana leksikal bahasa kedua itu menjalankan fungsinya dalam korpus bahasa pertama untuk mengungkapkan sesuatu konsep, peristiwa, perkara atau pemikiran apabila 
digunakan secara bersama-sama. Sehubungan itu, dengan menggunakan pendekatan semantik, penjelasan yang lebih berautoritis mampu dilakukan, lebih-lebih lagi dengan menggunakan teori semantik terkini.

\section{Objektif Kajian}

1. Menganalisis perkaitan pemikiran masyarakat peribumi Sabah dengan leksis bahasa sukuan singkowoton berdasarkan Pendekatan Semantik Ranah.

2. Menghuraikan penggunaan leksis bahasa sukuan peribumi Sabah, singkowoton dalam data korpus bahasa Melayu dengan menggunakan pendekatan Semantik Ranah.

\section{Metodologi Kajian}

Kajian ini menggunakan kaedah kepustakaan dan analisis teks. Teks yang dianalisis ialah data korpus yang dibangunkan penyelidik sendiri, iaitu terdiri daripada enam buah novel yang berlatarbelakangkan masyarakat peribumi Sabah. Karya novel-novel itu ialah hasil garapan dua orang penulis yang telah mapan, iaitu Azmah Nordin dengan karyanya bertajuk Dukanya Abadi Kukui Dari Dalam Cermin dan Debu Menerpa serta novelnovel Amil Jaya yang berjudul Bagaton dan Mariga. Kekuatan novel ini dipilih ialah novel ini menggunakan bahasa sukuan dan penulisnya antara yang tersohor dan sering mendapat anugerah penulisan novel pada peringkat kebangsaan dan antarabangsa.

Menerusi data korpus juga, maklumat senarai perkataan dan konkordans, iaitu senarai kata dalam korpus yang disusun mengikut abjad, penyataan tentang kedudukan dan penggunaannya dalam ayat, serta maklumat tentang makna kata berdasarkan konteks penggunaannya dapat diperoleh dengan mudah. Dengan cara ini, analisis secara sistematik dapat dijalankan. Konkordans ialah penggunaan kata yang terdapat dalam sekumpulan kata dengan kata tersebut terletak di tengah-tengah. Dalam hal ini, hubungan leksis dengan leksis dalam seperangkat ayat juga boleh memberikan gambaran makna yang diketengahkan. Hubungan antara leksis ini dapat dilihat menerusi kolokasi, iaitu bentuk-bentuk unit leksis yang hadir serentak dalam satu set frasa (Melcuk, 2001). Dengan melihat 
pola kolokasi bahasa tabii, pemilihan kata yang lebih relevan berdasarkan situasi dan konteks, makna yang tepat akan diperoleh. Hal ini bermaksud kosa kata tersebut mempunyai lingkungan teksnya sendiri (Norliza, 2000). Baris-baris konkordans akan memberikan maklumat tentang polapola bahasa yang akan terbit (Hunston, 2002)

Dalam menelusuri, meneroka dan menganalisis data-data korpus tersebut, penyelidik akan menggunakan Pendekatan Semantik Ranah (Fillmore 1982, 2003). Sehubungan dengan itu, prosedur pelaksanaan kajian dan mekanisme analisis dengan menggunakan teori akan turut diketengahkan dalam kajian ini.

\section{Perbincangan Kajian}

Pendekatan Semantik Ranah merupakan landasan yang digunakan dalam melihat gelagat pemakaian leksis bahasa sukuan dalam korpus bahasa Melayu. Teras teori ini ialah ranah (frame), iaitu representasi yang membekalkan latar dan motivasi bagi kewujudan dan penggunaan lazim sesuatu kata dalam sesuatu bahasa (Atkins dan Rundell, Fillmore, 2006, Fillmore dan Baker, 2010). Teori ini menjelaskan potensi gabungan sesuatu item leksikal dan penjelasannya berasaskan paparan eksplisit sesuatu elemen ranah yang direalisasikan pada struktur permukaan sama ada secara sintaksis mahupun leksikal. Fillmore (1975) menyatakan bahawa makna suatu leksis haruslah dilihat berasaskan hubungan antara ranahranah yang wujud. Analisis makna mesti mengambil kira bahasa alami, dan sesuatu kata itu lebih mudah difahami dalam konteks sama ada dalam bentuk peristiwa atau situasi penggunaannya. Ranah yang terbit ini merupakan struktur pengetahuan yang diperlukan untuk pemahaman dan penggunaan yang sesuai bagi setiap item leksikal atau frasa yang tertentu. Menurut teori Semantik Ranah, setiap ranah mempunyai unsur ranah yang dikenali sebagai elemen-elemen ranah yang berfungsi untuk mendukung ranah tersebut.

Di sini, Charles Fillmore telah mengemukakan satu pendekatan yang khusus tentang analisis semantik bahasa alami. Setiap unit linguistik, iaitu leksis untuk setiap latarnya akan menerbitkan ranah yang merupakan struktur pengetahuan dan pengalaman yang bermanfaat untuk pemahaman. Hal ini juga menentukan penggunaan yang sesuai bagi setiap 
item leksis atau frasa tertentu dalam suatu ayat. Setiap ranah semantik menstrukturkan maklumat latar belakang sesuatu kata, yang akan membentuk pelbagai fasa, peserta dan peralatan. Sementara itu, setiap ranah yang wujud itu pula mengandungi elemen ranah (ER) yang terlibat dalam pengkonseptualisasian ke atas ranah tersebut. Satu ranah itu mewakili satu pilihan linguistik yang berkaitan dengan satu situasi tertentu. Ini menjelaskan lagi bahawa ranah merupakan satu sistem konsep yang saling berhubung kait. Makna keseluruhan sesuatu konsep tersebut didukung oleh kehadiran ranah-ranah yang lain. Sehubungan itu, berdasarkan data yang dikaji, kehadiran leksis bahasa sukuan singkowoton akan diperihalkan untuk melihat unsur motivasi dan potensi leksis tersebut yang hadir bersama-sama dengan leksis bahasa Melayu.

\section{Konsep Singkowoton dalam Masyarakat Peribumi Sabah}

Pada zaman dahulu, singkowoton merupakan satu lambang keperkasaan, kejantanan, kemenangan dan kecemerlangan seorang pahlawan dalam masyarakat Murut kerana keberaniannya untuk melakukan pembunuhan dengan cara memenggal kepala musuh. Kebiasaannya, aktiviti ngayau, iaitu operasi memburu kepala musuh dilakukan di kampung-kampung untuk mengukuhkan lagi lambang prestij kepahlawanan. Masyarakat mereka percaya bahawa, kepala yang dipenggal tersebut amat sesuai dijadikan sebagai singkowoton kerana mempunyai roh semangat (Okumura. M \& Siew. Y.Y, 2013). Dalam masyarakat Murut yang hidup sebagai petani dan sering meneroka kawasan pertanian dan penempatan baru, proses membina dan mendirikan rumah sudah menjadi lumrah. Tanah baru yang diterokai dipercayai mempunyai semangat yang perlu dihormati. Justeru, singkowoton akan dijadikan sebagai perantara untuk berkomunikasi dengan roh semangat tersebut. Singkowoton harus digantung sebelum upacara masayau, iaitu upacara memindahkan roh dari rumah lama ke rumah baharu.

Di samping itu, singkowoton juga dijadikan sebagai hadiah yang amat bernilai dalam upacara-upacara tertentu. Abd. Hakim Mohamad (2014) menyatakan bahawa singkowoton akan digantung di tinitundap (batang kayu yang dibina khas di tengah-tengah bahagian atas lansaran). Singkowoton yang digantung pada tiang tersebut biasanya digunakan semasa upacara tarian lansaran. Semasa tarian berlangsung, para penari 
akan melonjak-lonjak untuk mendapatkan singkowoton yang tergantung di tiang di tengah-tengah tapak tarian tersebut. Sesiapa yang berjaya mendapat atau menggapainya akan diisytiharkan sebagai pemenang dan dikategorikan sebagai pahlawan yang unggul .

\section{Maklumat konseptual leksis Singkowoton}

Berpandukan data korpus, leksis singkowoton memiliki makna teras yang bermaksud tengkorak manusia yang telah dipenggal. Hasil analisis yang dijalankan menunjukkan bahawa gelagat semantik leksis singkowoton berfungsi dalam dua elemen ranah, iaitu elemen ranah BENDA dan elemen ranah KEPERCAYAAN. Maklumat ranah tersebut boleh diperoleh melalui maklumat konseptual sesuatu leksis, yakni memberikan maklumat latar akan kewujudan leksis tersebut dalam gugusan ayat.

Analisis yang dilakukan ke atas data korpus menunjukkan bahawa leksis singkowoton telah hadir sebanyak 41 kali dalam pelbagai ayat konkordans. Justeru, bersumberkan data sebanyak 41 itu, maka analisis untuk mengenal pasti maklumat konseptual telah dilaksanakan. Maklumat konseptual dalam leksis singkowoton ditunjukkan seperti jadual yang berikut:

Jadual 1: Maklumat konseptual Singkowoton

\begin{tabular}{|c|c|c|c|}
\hline Lema & Ranah & Elemen Ranah & Elemen Ranah \\
\hline \multirow{3}{*}{ Singkowoton } & \multirow{3}{*}{ TENGKORAK } & BENDA & SUMBER + OBJEK \\
\cline { 3 - 4 } & & \multirow{2}{*}{ KEPERCAYAAN } & SUBJEK + SASARAN \\
\cline { 3 - 4 } & & & $\begin{array}{c}\text { SUBJ EK + PERKARA GHAIB + PERKARA GHAIB } \\
\text { OBJEK }\end{array}$ \\
\cline { 3 - 4 } & & &
\end{tabular}

\section{Analisis Lema Singkowoton}

Berdasarkan data korpus yang dianalisis, kajian ini mengenal pasti bahawa lema singkowoton mempunyai makna teras, iaitu tengkorak manusia yang 
telah dipenggal. Makna teras tersebut diserlahkan menerusi dua ranah, iaitu ranah BENDA dan ranah KEPERCAYAAN. Ranah BENDA pula terkandung dalamnya dua kombinasi elemen ranah, iaitu kombinasi pertama elemen ranah SUMBER dan elemen ranah OBJEK, manakala kombinasi kedua pula ialah elemen ranah SUBJEK dan elemen ranah SASARAN. Sementara itu, ranah KEPERCAYAAN pula diserlahkan menerusi dua kombinasi, iaitu elemen ranah OBJEK dan PERKARA GHAIB serta elemen ranah SUBJEK, elemen ranah PERKARA GHAIB dan elemen ranah OBJEK.

Kajian ini mendapati bahawa leksis singkowoton membawa makna tengkorak manusia yang telah dipenggal ialah makna teras. Makna teras diwakili oleh elemen ranah BENDA dan elemen ranah KEPERCAYAAN. Elemen ranah BENDA mengandungi elemen ranah SUMBER dan elemen ranah OBJEK direalisasikan oleh rangkaian leksis dalam data korpus seperti leksis akan kita jadikan singkowoton, bagus sekali dijadikan singkowoton, yang menjadi singkowoton dan yang dijadikan singkowoton untuk membawa makna suatu barang yang berharga (Kamus Dewan, 2013). Selain itu, pewujudan leksis-leksis seperti harus dipuja, bergayutan seolah-olah memanggilnya, singkowoton masih hidup bergoyang-goyang, memuja roh tengkorak, upacara memuja roh, semangat singkowoton dan roh semangat singkowoton telah menyerlahkan lagi elemen ranah KEPERCAYAAN yang merujuk kepada keyakinan atau akuan akan benarnya sesuatu perkara yang berlaku (Kamus Dewan, 2013).

\section{Analisis ranah TENGKORAK}

Berdasarkan data yang dikaji, ranah TENGKORAK diterbitkan oleh dua elemen ranah, iaitu elemen ranah BENDA dan elemen ranah KEPERCAYAAN. Elemen ranah BENDA mempunyai dua kombinasi elemen ranah, iaitu (SUMBER + OBJEK) dan (SUBJEK + SASARAN). Sementara itu, elemen ranah KEPERCAYAAN juga mengandungi dua kombinasi, iaitu (OBJEK + PERKARA GHAIB) dan (SUBJEK + PERKARA GHAIB + OBJEK). Penjelasan setiap ranah tersebut dihuraikan seperti yang berikut. 


\section{Analisis ranah BENDA (SUMBER + OBJEK)}

Elemen ranah BENDA ini terdiri daripada elemen ranah SUMBER dan elemen ranah OBJEK. Elemen ranah BENDA bermaksud suatu OBJEK yang diperoleh atau dihasilkan daripada sesuatu SUMBER. Paparan maklumat ditunjukkan dalam jadual di bawah.

Jadual 2: Maklumat analisis linguistik ranah BENDA

(SUMBER + OBJEK)

\begin{tabular}{ll}
\hline Lema & Singkowoton \\
\hline Unit Leksikal & Singkowoton \\
Kelas Kata & Kata Nama \\
Ranah TENGKORAK & Terserlah menerusi elemen ranah BENDA \\
Elemen ranah BENDA & OBJEK iaitu suatu benda atau bahan yang diperoleh atau \\
& dihasilkan daripada suatu SUMBER \\
Elemen Ranah & BENDA (SUMBER dan OBJEK) \\
Struktur Nahu & FN + FK \\
& SUMBER + OBJEK \\
Contoh ayat & 1. Kepala-kepala itu akan kita jadikan singkowoton. \\
& 2. Kepala itu lonjonglah, bagus sekali dijadikan singkowoton. \\
& 3. Tengkorakyang menjadi singkowoton itu ada bersama-sama kita. \\
& 4. Tengkorak-tengkorak manusia yang dijadikan singkowoton. \\
\hline
\end{tabular}

Berdasarkan jadual di atas, makna ranah bermaksud BENDA, terdiri daripada elemen ranah SUMBER yang merupakan bahan atau benda asal yang digunakan untuk dijadikan OBJEK, iaitu singkowoton. Dua elemen yang terdapat dalam ranah ini ialah ranah SUMBER yang dirujuki sebagai leksis kepala-kepala, tengkorak-tengkorak, kepala itu lonjonglah dan tengkorak manakala leksis singkowoton telah merealisasikan elemen ranah OBJEK yang dirujuk sebagai benda atau bahan yang dihasilkan daripada SUMBER tadi.

Berdasarkan konteks kajian, leksis singkowoton yang digandingkan dengan leksis-leksis perbuatan seperti jadikan, dijadikan dan menjadi telah berjaya bertindak sebagai hasil, akibat atau manfaat yang diperoleh daripada sesuatu. Ini bererti bahawa leksis singkowoton telah menyempurnakan maksud ayat, iaitu tengkorak manusia yang telah 
dipenggal. Selain itu, perwujudan leksis-leksis seperti kepala-kepala itu, kepala itu lonjonglah, tengkorak dan tengkorak-tengkorak manusia telah menerbitkan elemen ranah SUMBER, iaitu punca atau asal sesuatu perkara atau benda (Kamus Dewan, 2013). Seterusnya, deskripsi semantik dapat menghujahkan bahawa gabungan kombinasi antara elemen ranah SUMBER dan elemen ranah OBJEK telah berjaya menyerlahkan lagi elemen ranah BENDA, iaitu barang atau harta yang berharga (Kamus Dewan, 2013). Hubungan lengkap melengkapi antara leksis dengan leksis dan ranah dengan ranah menggambarkan bahawa wujudnya elemen ranah yang berlapis-lapis antara ranah-ranah tersebut.

\section{Analisis ranah BENDA (SUBJEK + SASARAN)}

Elemen ranah BENDA ini juga diserlahkan melalui kombinasi kedua, iaitu terdiri daripada elemen ranah SUBJEK dan elemen ranah SASARAN. Di sini, elemen ranah BENDA bermaksud suatu SASARAN untuk dicapai, dipenuhi, atau dimanfaatkan oleh SUBJEK. Paparan maklumat ditunjukkan dalam jadual di bawah.

Jadual 3: Maklumat analisis linguistik elemen ranah BENDA (SUBJEK + SASARAN)

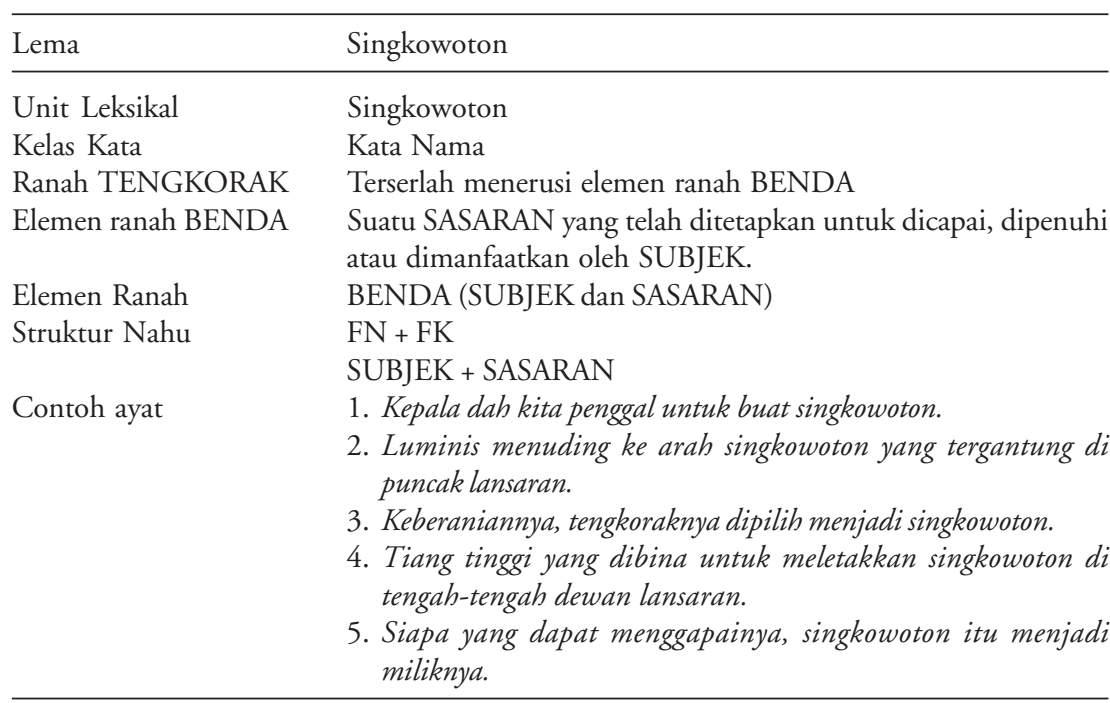


Berdasarkan jadual di atas, makna ranah bermaksud BENDA, yang terdiri daripada elemen ranah SASARAN, iaitu singkowoton yang merupakan matlamat atau tujuan yang telah ditetapkan untuk dicapai, dipenuhi atau dimanfaatkan oleh SUBJEK, iaitu perkara yang menjadi punca atau asal sesuatu perkara. Leksis singkowoton berfungsi sebagai fokus matlamat untuk dicapai lebih terserlah apabila digandingkan dengan leksis-leksis seperti untuk buat, menuding ke arah, dipilih menjadi, untuk meletakkan dan dapat menggapainya yang membawa makna tujuan yang hendak dipenuhi.

Seterusnya, elemen ranah leksis SUBJEK pula direalisasikan oleh beberapa leksis seperti leksis kepala, Luminis, keberaniannya tengkoraknya, tiang tinggi, dan siapa yang bermaksud perkara atau individu yang dimanfaatkan atau bertindak ke arah mencapai sasaran. Huraian semantik ranah dapat membuktikan bahawa elemen ranah BENDA diterbitkan oleh elemen ranah SUBJEK dan elemen ranah SASARAN. Hubungan saling melengkapi antara leksis menyerlahkan lagi peranannya dalam ayat. Seterusnya, elemen ranah SUBJEK yang berhubung kait dengan elemen ranah SASARAN menerusi jaringan unit leksikal telah menerbitkan elemen ranah BENDA yang menyerlahkan lagi ranah TENGKORAK.

\section{Analisis KEPERCAYAAN (OBJEK + PERKARA GHAIB)}

Elemen ranah KEPERCAYAAN ini dapat dibahagikan kepada dua elemen ranah, iaitu elemen ranah OBJEK dan elemen ranah PERKARA GHAIB. Elemen ranah KEPERCAYAAN bermaksud bahawa suatu OBJEK itu dapat mendatangkan atau menimbulkan PERKARA GHAIB. Paparan maklumat ditunjukkan dalam jadual di bawah. 
Jadual 4: Maklumat analisis linguistik ranah KEPERCAYAAN (OBJEK + PERKARA GHAIB)

\begin{tabular}{|c|c|}
\hline Lema & Singkowoton \\
\hline Unit Leksikal & Singkowoton \\
\hline Kelas Kata & Kata Nama \\
\hline Ranah TENGKORAK & Terserlah menerusi elemen ranah KEPERCAYAAN \\
\hline Elemen ranah KEPERCAYAAN & $\begin{array}{l}\text { OBJEK iaitu suatu benda yang dapat mendatangkan } \\
\text { atau menimbulkan unsur-unsur PERKARA GHAIB }\end{array}$ \\
\hline Elemen Ranah & KEPERCAYAAN (OBJEK dan PERKARA GHAIB) \\
\hline Struktur Nahu & $\mathrm{FN}+\mathrm{FK}$ \\
\hline Contoh ayat & $\begin{array}{l}\text { 1. Singkowoton yang harus dipuja. } \\
\text { 2. Namun, singkowoton masih kekal terikat, bergayutan } \\
\text { seolah-olah memangilnya. } \\
\text { 3. Sudah cukup singkowoton dipersembahkan pada kita. } \\
\text { 4. Tiba-tiba tampak olehnya, singkowoton itu hidup, } \\
\text { bergoyang-goyang. } \\
\text { 5. Kalau singkowoton itu tengkoraknya pendekar, akan } \\
\text { menjadi sangat kuat. }\end{array}$ \\
\hline
\end{tabular}

Berdasarkan jadual di atas, makna ranah bermaksud KEPERCAYAAN, terdiri daripada elemen ranah OBJEK yang merupakan suatu benda yang dapat mendatangkan atau menimbulkan PERKARA GHAIB, iaitu sesuatu perkara yang aneh atau ajaib (Kamus Dewan, 2013). Dua elemen yang terdapat dalam ranah ini ialah ranah OBJEK yang dirujuki sebagai leksis singkowoton, iaitu tengkorak manusia yang dipenggal yang akan menimbulkan PERKARA GHAIB yang direalisasikan oleh leksis seperti harus dipuja, bergayutan seolah-olah memanggilnya, dipersembahkan pada kita, dan akan menjadi sangat kuat.

Berdasarkan data kajian, perlakuan ke atas singkowoton telah menjadi faktor penyebab berlakunya perkara-perkara yang aneh atau ajaib. Hadirnya leksis singkowoton telah menyebabkan perwujudan leksis-leksis lain yang menggambarkan perkara pelik. Realisasi leksis singkowoton telah berjaya menerbitkan elemen ranah OBJEK, iaitu sesuatu yang dapat disentuh manakala hubungan kombinasinya dengan elemen ranah PERKARA GHAIB pula telah menyerlahkan lagi fungsinya dalam konstituen ayat. Perkaitan antara elemen ranah OBJEK dan elemen ranah PERKARA GHAIB menerusi jaringan semantik leksikal telah berjaya 
menyuguhkan makna elemen ranah KEPERCAYAAN. Sementara itu, realisasi elemen ranah KEPERCAYAAN pula telah menyerlahkan ranah TENGKORAK.

\section{Analisis KEPERCAYAAN (SUBJEK + PERKARA GHAIB + OBJEK)}

Seterusnya, kombinasi kedua ranah KEPERCAYAAN ini ialah terdiri daripada tiga elemen ranah, iaitu elemen ranah SUBJEK, elemen ranah PERKARA GHAIB dan elemen ranah OBJEK. Elemen ranah KEPERCAYAAN bermaksud bahawa suatu unsur PERKARA GHAIB yang berlaku digerakkan oleh SUBJEK untuk manfaat suatu OBJEK. Paparan maklumat ditunjukkan dalam jadual di bawah.

Jadual 5: Maklumat analisis linguistik ranah KEPERCAYAAN (SUBJEK + PERKARA GHAIB + OBJEK)

\begin{tabular}{|c|c|}
\hline Lema & Singkowoton \\
\hline Unit Leksikal & Singkowoton \\
\hline Kelas Kata & Kata Nama \\
\hline Ranah TENGKORAK & Terserlah menerusi elemen ranah KEPERCAYAAN \\
\hline Elemen ranah KEPERCAYAAN & $\begin{array}{l}\text { PERKARA GHAIB atau perkara ghaib yang ditimbulkan } \\
\text { oleh SUBJEK untuk manfaat suatu OBJEK, iaitu } \\
\text { tengkorak manusia }\end{array}$ \\
\hline Elemen Ranah & $\begin{array}{l}\text { KEPERCAYAAN (SUBJEK + PERKARA GHAIB + } \\
\text { OBJEK) }\end{array}$ \\
\hline Struktur Nahu & $\begin{array}{l}\text { FN + FK } \\
\text { SUBJEK + PERKARA GHAIB + OBIEK }\end{array}$ \\
\hline Contoh ayat & $\begin{array}{l}\text { 1. Mereka memuja roh tengkorak yang menjadi } \\
\text { singkowoton. } \\
\text { 2. Upacara memuja roh singkowoton dilangsungkan. } \\
\text { 3. Dia seperti lupa kepada semangat singkowoton yang } \\
\text { dikutuk habis-habisan tadi. } \\
\text { 4. Seterusnya, kampung ini punya roh semangat memiliki } \\
\text { singkowoton. }\end{array}$ \\
\hline
\end{tabular}

Berdasarkan jadual di atas, makna ranah bermaksud KEPERCAYAAN, terdiri daripada elemen ranah PERKARA GHAIB yang berlaku atas aksi oleh SUBJEK untuk manfaat OBJEK. Tiga elemen yang terdapat dalam ranah ini ialah elemen ranah SUBJEK, iaitu bermaksud perkara atau individu yang mendorong berlakunya sesuatu yang 
direalisasikan oleh leksis-leksis seperti mereka, upacara, dia, dan kampung ini, manakala elemen ranah PERKARA GHAIB yang dirujuki sebagai perbuatan aneh atau ajaib yang diserlahkan menerusi leksis-leksis seperti memuja roh, semangat, dan roh semangat serta elemen ranah OBJEK, iaitu kepala manusia yang telah dipenggal direalisasikan oleh leksis singkowoton.

Bersandarkan konteks singkowoton dalam data yang dikaji, hal ini membuktikan bahawa masyarakat peribumi merujuk singkowoton sebagai tengkorak manusia yang telah dipenggal untuk dijadikan pemujaan. Dengan menggunakan deskripsi semantik ranah, leksis singkowoton telah berjaya menggerakkan kewujudan leksis-leksis seperti memuja roh, semangat dan roh semangat yang menggambarkan PERKARA GHAIB serta leksis-leksis mereka, upacara, dia dan kampung ini yang bertindak sebagai penggerak untuk melakukan sesuatu. Kewujudan setiap leksis menunjukkan hubungan yang saling melengkapi dan kelihatan begitu kompleks. Dapatan membuktikan bahawa elemen ranah KEPERCAYAAN diterbitkan oleh elemen ranah SUBJEK, elemen ranah OBJEK dan elemen ranah PERKARA GHAIB. Selanjutnya, elemen ranah KEPERCAYAAN ini menyerlahkan lagi ranah TENGKORAK.

\section{Pemetaan Ranah Singkowoton}

Selanjutnya, dalam proses pemetaan ranah, maklumat-maklumat leksis seperti lema, pola valensi dan analisis tatatingkat adalah amat penting untuk mengetahui latar belakangnya. Dalam hal ini, Fillmore (1982) menjelaskan bahawa pemetaan ranah merupakan rangka pengetahuan yang menyepadukan jenis-jenis pengalaman yang diperoleh daripada analisis konsep. Dengan merujuk analisis yang telah dilakukan ke atas unit-unit leksikal yang terdapat dalam data yang dikaji, kajian ini telah mengenal pasti proses pemetaan ranah TENGKORAK yang melibatkan hubungan yang saling melengkapi antara elemen-elemen ranah yang terbit. Berikut, ditunjukkan hubungan elemen-elemen ranah yang diperoleh daripada analisis tatatingkat ranah yang telah dilakukan.

\section{Ranah TENGKORAK}

Ranah TENGKORAK terdiri daripada elemen ranah BENDA dan elemen ranah KEPERCAYAAN. Setiap elemen ranah tersebut diterbitkan oleh 
elemen ranah yang saling berkaitan dan unit-unit leksikal yang berhubungan.

\section{Ranah BENDA (SUMBER + OBJEK)}

Elemen ranah BENDA mengandungi elemen ranah SUMBER dan elemen ranah OBJEK. Hubungan ranah BENDA berdasarkan elemennya yang mengandungi elemen ranah SUMBER + OBJEK yang diteliti tidak dapat difahami secara terpisah tanpa penjelasan proses yang saling melengkapi. Hal ini disebabkan oleh hubungan antara satu leksis dengan leksis serta kaitan antara elemen ranah dengan elemen ranah itu mengandung ciri-ciri makna yang menyerlahkan lagi makna ranah BENDA.

Pemetaan Ranah TENGKORAK (BENDA (SUMBER + OBJEK)

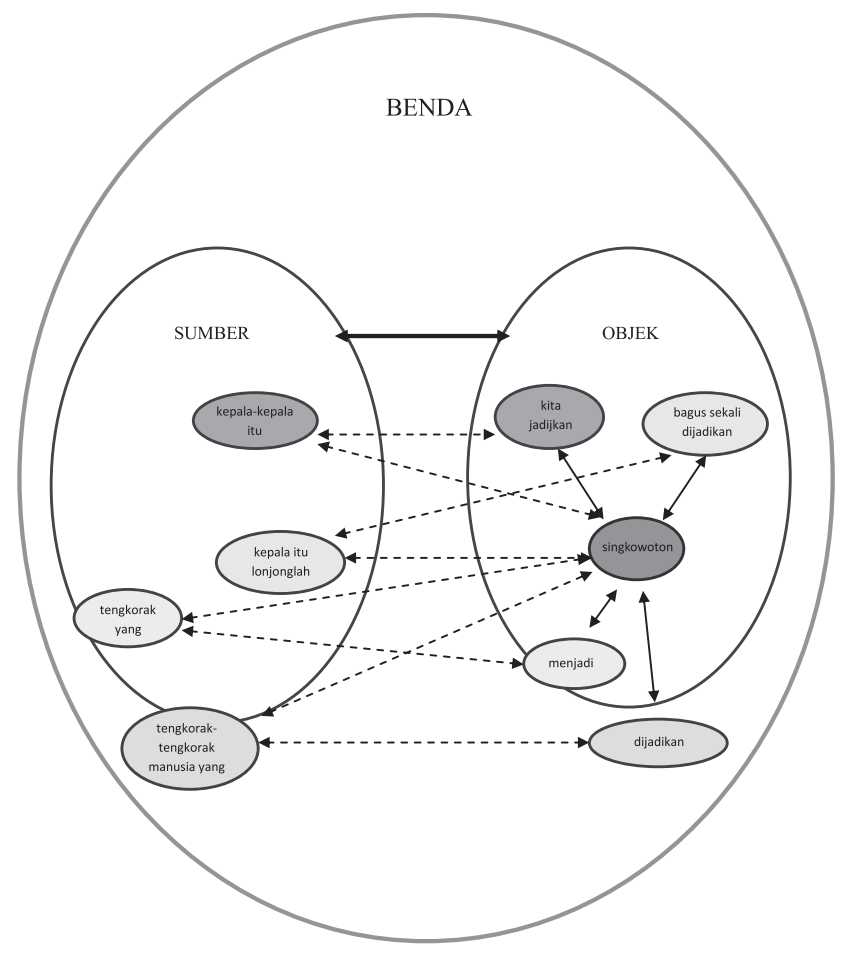

Rajah 1: Pemetaan Ranah BENDA (SUMBER + OBJEK) 
Berdasarkan data yang dikaji, elemen ranah BENDA telah ditonjolkan melalui elemen ranah SUMBER dan elemen ranah OBJEK. Menurut Kamus Dewan (2013), BENDA bermaksud barang atau harta yang berharga atau bernilai. Sehubungan itu, berpandukan jadual di atas, dapat dibuktikan bahawa elemen ranah telah direalisasi oleh beberapa unit leksis yang menjadi latarnya. Sebagai contoh, elemen ranah SUMBER yang bermakna punca atau asal kejadian sesuatu perkara, peristiwa atau benda (Kamus Dewan, 2013) terserlah melalui leksis-leksis seperti kepalakepala itu, kepala itu lonjonglah, tengkorak yang dan tengkorak-tengkorak manusia yang membawa maksud asal sesuatu benda itu dihasilkan. Buktibukti tersebut menggambarkan bahawa leksis singkowoton adalah hasilan daripada sesuatu benda.

Seterusnya, rangkaian leksis seperti akan kita jadikan singkowoton, bagus sekali dijadikan singkowoton, menjadi singkowoton itu ada bersamasama kita dan dijadikan singkowoton pula ialah realisasi leksis yang menyerlahkan makna elemen ranah OBJEK, iaitu benda atau harta yang bernilai. Elemen ranah tersebut merujuk benda yang terhasil daripada sesuatu. Selanjutnya, konsep unit-unit leksis yang ditandai oleh bulatan kecil sebenarnya merupakan realisasi leksis yang telah menyerlahkan elemen ranah SUMBER dan elemen ranah OBJEK, iaitu lingkaran besar yang berwarna biru seperti dalam rajah. Setiap elemen ranah tersebut mempunyai jaringan antara satu dengan yang lain yang ditandai dengan simbol anak panah untuk menerbitkan elemen ranah BENDA yang divisualkan dalam satu bulatan besar berwarna merah. Anak panah terputus-putus pula menunjukkan bahawa rangkaian setiap konsep unit leksikal dalam bentuk struktur ayat menyerlahkan lagi elemen ranah tersebut yang membawa makna bahawa leksis singkowoton mempunyai hubungan melengkapi secara langsung dengan beberapa leksis yang hadir bersama-samanya. Seterusnya, gabungan antara unit leksis sebagai peranti semantik telah menyuguhkan makna untuk elemen ranah SUMBER dan elemen ranah OBJEK sehingga terserlah elemen ranah BENDA.

\section{Ranah BENDA (SUBJEK + SASARAN)}

Ranah BENDA mengandungi elemen ranah SUBJEK dan elemen ranah SASARAN. Hubungan ranah BENDA berdasarkan elemennya yang mengandungi elemen ranah SUBJEK + SASARAN yang diteliti tidak 
dapat difahami secara terpisah tanpa penjelasan proses yang saling melengkapi. Hal ini disebabkan oleh hubungan antara satu leksis dengan leksis serta kaitan antara elemen ranah dengan elemen ranah itu mengandungi ciri-ciri makna yang menyerlahkan lagi makna ranah BENDA.

\section{Pemetaan Ranah TENGKORAK (BENDA (SUBJEK + SASARAN)}

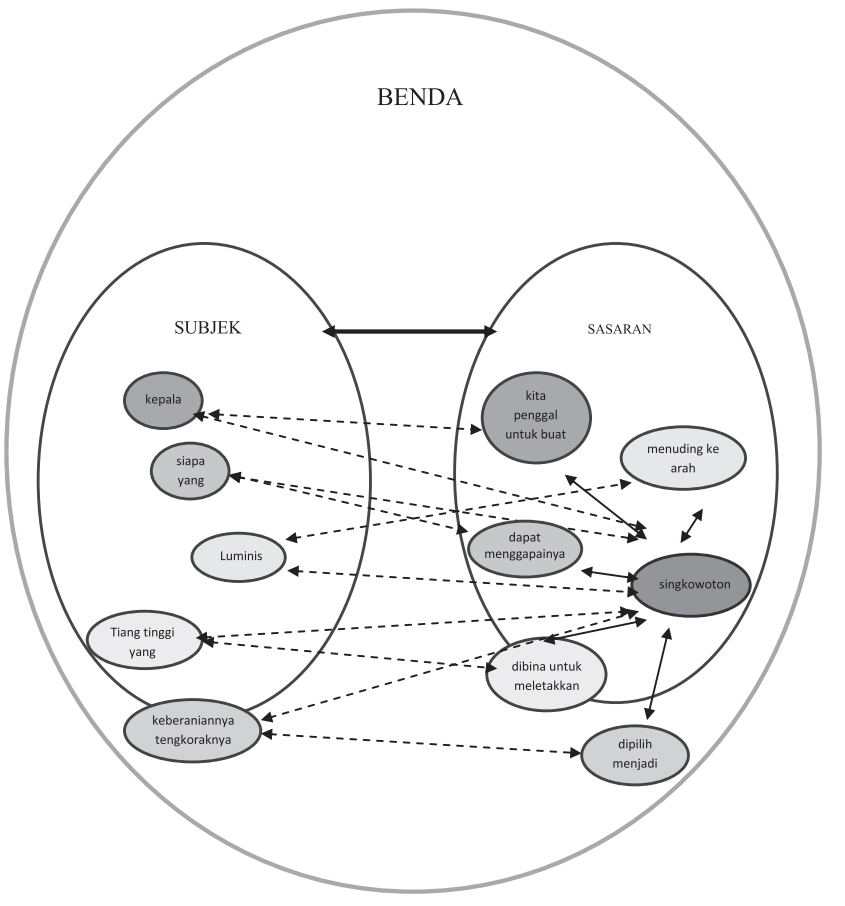

Rajah 2: Pemetaan Ranah BENDA (SUBJEK+ SASARAN)

Berdasarkan data yang dikaji, elemen ranah BENDA telah ditonjolkan melalui elemen ranah SUBJEK dan elemen ranah SASARAN. Berpandukan Rajah 2 di atas, dapat dibuktikan bahawa elemen ranah telah direalisasi oleh beberapa unit leksis yang menjadi asasnya. Misalnya, elemen ranah SUBJEK yang membawa topik perbincangan atau fokus pemerihalan terserlah menerusi leksis-leksis seperti kepala, Luminis, keberaniannya tengkoraknya, tiang tinggi yang dan siapa yang membawa maksud penggerak kepada perbuatan yang dilakukan ke atas sesuatu. 
Bukti-bukti tersebut menggambarkan bahawa tindakan; sama ada digerakkan oleh SUBJEK atau pun ke atas SUBJEK sebenarnya dirujuk untuk memberikan manfaat atau bertujuan melengkapkan maksud singkowoton.

Seterusnya, leksis-leksis seperti ah kita penggal untuk buat singkowoton, menuding ke arah singkowoton yang tergantung di puncak lansaran, dipilih menjadi singkowoton, dibina untuk meletakkan singkowoton di tengah-tengah dewan lansaran dan dapat menggapainya singkowoton itu menjadi miliknya ialah realisasi leksis yang menyerlahkan makna elemen ranah SASARAN, iaitu tujuan yang hendak dicapai (Kamus Dewan, 2012). Elemen ranah SASARAN merupakan hasil atau matlamat akhir yang hendak disempurnakan daripada suatu perbuatan. Berdasarkan rajah di atas, beberapa bulatan kecil berwarna coklat merupakan realisasi leksis yang telah menyerlahkan elemen ranah SUBJEK dan elemen ranah SASARAN. Kedua-dua elemen ranah tersebut digambarkan dengan satu bulatan yang berwarna biru yang bermaksud elemen ranah yang mengandungi konsep unit leksikal masing-masing.

Selanjutnya, kombinasi hubungan antara kedua-dua elemen ranah yang dilambangkan dengan simbol anak panah telah menyerlahkan lagi elemen ranah BENDA yang ditunjukkan melalui satu bulatan besar berwarna merah. Anak panah terputus-putus pula menunjukkan bahawa rangkaian setiap konsep unit leksikal dalam bentuk struktur ayat menyerlahkan lagi elemen ranah tersebut. Leksis singkowoton yang menjadi fokus kajian dilihat mempunyai hubungan dengan leksis-leksis yang hadir secara bersama-samanya, yang digambarkan dengan anak panah. Jaringan semantik tersebut telah berjaya menonjolkan makna elemen ranah SUBJEK dan elemen ranah SASARAN sehingga terserlah elemen ranah BENDA.

\section{Ranah KEPERCAYAAN (OBJEK + PERKARA GHAIB)}

Ranah KEPERCAYAAN mengandungi elemen ranah OBJEK dan elemen ranah PERKARA GHAIB. Hubungan ranah KEPERCAYAAN berdasarkan elemennya yang mengandung elemen ranah OBJEK + PERKARA GHAIB dapat difahami dengan lebih mudah jika tidak diteliti secara terpisah tanpa penjelasan proses yang saling melengkapi. Hal ini 
disebabkan oleh hubungan antara satu leksis dengan leksis serta kaitan antara elemen ranah dengan elemen ranah itu mengandungi ciri-ciri makna yang menyerlahkan lagi makna ranah KEPERCAYAAN.

Pemetaan Ranah TENGKORAK (KEPERCAYAAN (OBJEK + PERKARA GHAIB)

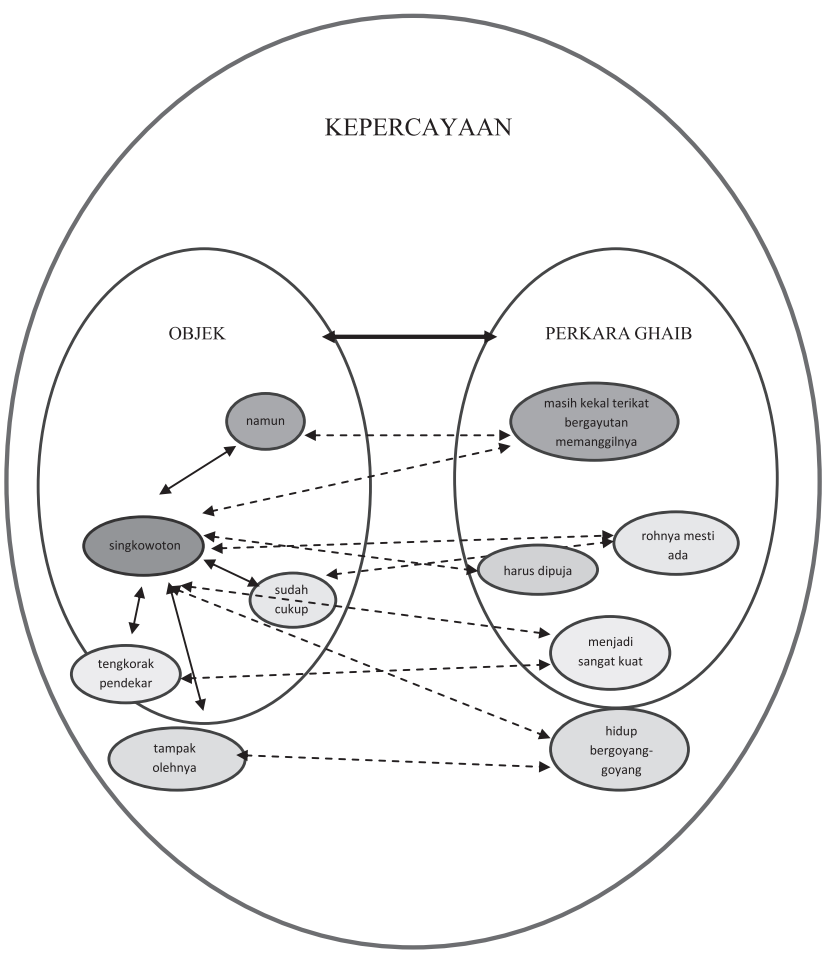

Rajah 3: Pemetaan Ranah KEPERCAYAAN

(OBJEK + PERKARA GHAIB)

Berdasarkan data yang dikaji, ranah KEPERCAYAAN telah ditonjolkan melalui elemen ranah OBJEK dan elemen ranah PERKARA GHAIB. Menurut Kamus Dewan (2013), KEPERCAYAAN bermaksud keyakinan atau akuan akan benarnya sesuatu perkara yang berlaku. Sehubungan itu, dapat dibuktikan bahawa elemen ranah telah direalisasi oleh beberapa unit leksis yang menjadi latar berpandukan jadual di atas. $\mathrm{Hal}$ ini dapat dilihat menerusi elemen ranah OBJEK yang bermaksud 
benda atau barang yang dapat disentuh atau dilihat (Kamus Dewan, 2013) terserlah menerusi leksis-leksis seperti singkowoton, namun singkowoton, sudah cukup singkowoton, tiba-tiba tampak olehnya singkowoton itu dan kalau singkowoton itu tengkorak pendekar membawa maksud suatu barangan yang bernilai. Bukti-bukti tersebut menggambarkan bahawa keistimewaan atau kedudukan barang berharga dalam masyarakat peribumi yang dirujuk sebagai singkowoton

Di samping itu, rangkaian leksis seperti yang harus dipuja, masih kekal terikat dan bergayutan seolah-olah memanggilnya, dipersembahkan kepada kita, seperti hidup bergoyang-goyang dan akan menjadi sangat kuat ialah pewujudan leksis yang menyerlahkan makna elemen ranah PERKARA GHAIB, iaitu perkara aneh atau ajaib yang tidak dapat dilihat (Kamus Dewan, 2013). Elemen ranah PERKARA GHAIB tersebut merupakan unsur-unsur mistik yang berlaku sebagai impak kewujudan singkowoton. Dalam pada itu, konsep unit-unit leksis yang ditandai oleh bulatan kecil berwarna coklat sebenarnya mewakili realisasi leksis yang menyerlahkan elemen ranah OBJEK dan elemen ranah PERKARA GHAIB. Kedua-dua elemen ranah tersebut digambarkan menerusi lingkaran besar yang berwarna biru seperti dalam rajah. Setiap elemen ranah tersebut pula saling lengkap melengkapi antara satu dengan yang lain yang ditandai dengan simbol anak panah untuk menerbitkan elemen ranah KEPERCAYAAN yang ditandai dengan satu bulatan besar berwarna merah. Anak panah terputus-putus pula menunjukkan bahawa rangkaian setiap konsep unit leksikal dalam bentuk struktur ayat menyerlahkan lagi elemen ranah tersebut. Leksis singkowoton menunjukkan bahawa leksis tersebut mempunyai jaringan secara langsung dengan beberapa leksis yang hadir bersama-samanya yang ditunjukkan melalui anak panah. Seterusnya, hubungan antara unit leksis sebagai jaringan semantik telah menerbitkan makna untuk elemen ranah OBJEK dan elemen ranah PERKARA GHAIB sehingga terserlah elemen ranah KEPERCAYAAN.

\section{Ranah KEPERCAYAAN (SUBJEK + PERKARA GHAIB + OBJEK)}

Seterusnya, ranah KEPERCAYAAN juga mengandungi elemen ranah SUBJEK, elemen ranah PERKARA GHAIB dan elemen ranah OBJEK. Hubungan ranah KEPERCAYAAN berdasarkan elemennya yang mengandungi elemen ranah SUBJEK + PERKARA GHAIB + OBJEK 
diteliti tidak dapat difahami secara terpisah tanpa penjelasan proses yang saling melengkapi. Hal ini disebabkan hubungan antara satu leksis dengan leksis serta kaitan antara elemen ranah dengan elemen ranah itu mengandungi ciri-ciri makna yang menyerlahkan lagi makna ranah KEPERCAYAAN.

Pemetaan ranah TENGKORAK (KEPERCAYAAN (SUBJEK + PERKARA GHAIB + OBJEK))

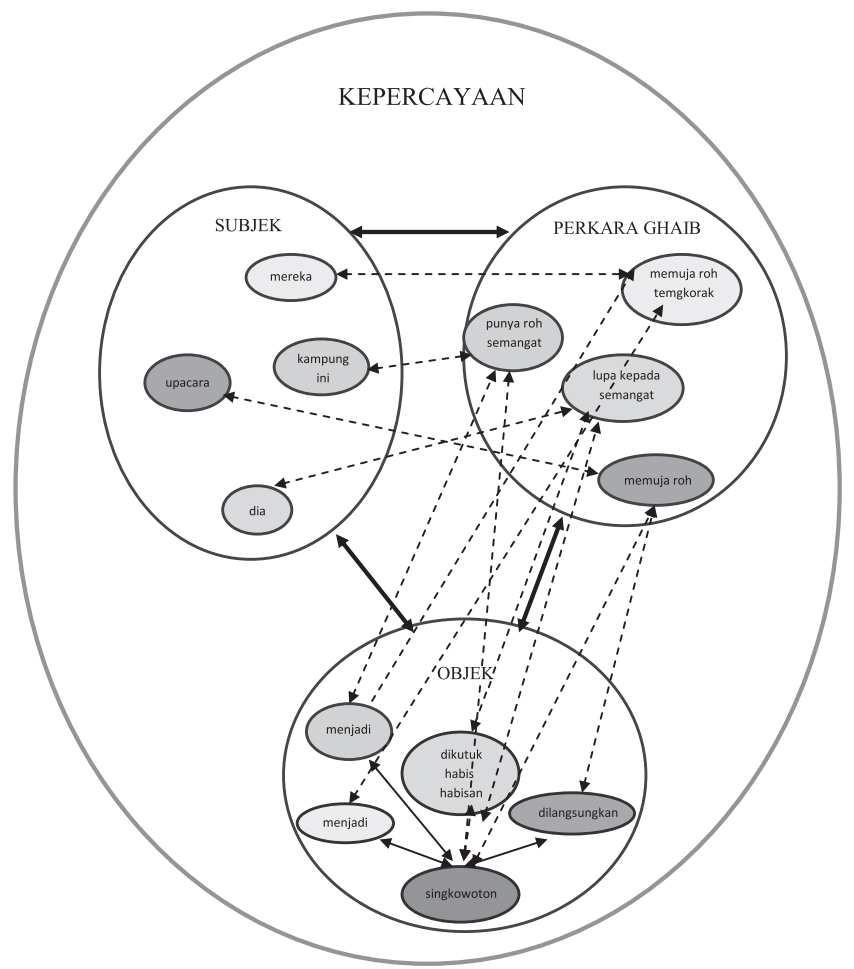

Rajah 4: Pemetaan elemen ranah TENGKORAK (SUBJEK + PERKARA GHAIB + OBJEK)

Berdasarkan data yang dikaji, elemen ranah KEPERCAYAAN juga telah diserlahkan menerusi elemen ranah SUBJEK, elemen ranah PERKARA GHAIB dan elemen ranah OBJEK. Menurut Kamus Dewan (2013), kepercayaan merupakan keyakinan atau keakuan akan benarnya 
sesuatu perkara atau kejadian. Jadual di atas membuktikan bahawa elemen ranah telah direalisasikan oleh beberapa konsep unit leksikal yang terkandung di dalamnya. Sebagai contoh, elemen ranah SUBJEK yang bermaksud perkara atau fokus perbincangan yang dapat menggerakkan yang melakukan sesuatu (Kamus Dewan, 2013) terserlah menerusi leksisleksis seperti mereka, upacara, dia dan seterusnya kampung ini,yang menunjukkan makna sesuatu perkara atau penggerak.

Dalam pada itu, konsep-konsep leksis seperti memuja roh tengkorak, memuja roh, seperti lupa kepada semangat dan punya roh semangat pula ialah realisasi leksis yang menyerlahkan makna elemen ranah PERKARA GHAIB, iaitu kejadian atau perkara aneh atau ajaib yang berlaku akibat daripada sesuatu (Kamus Dewan, 2013). Selain itu, elemen ranah OBJEK yang bermaksud benda atau barang bernilai yang dapat disentuh atau dilihat (Kamus Dewan, 2013) diserlahkan menerusi pewujudan leksisleksis seperti yang menjadi singkowoton, singkowoton dilangsungkan, singkowoton yang dikutuk habis-habisan tadi dan memiliki singkowoton. Jaringan leksis singkowoton bersama-sama Kata Kerja menjadi, dilangsungkan, dikutuk dan memiliki yang digambarkan melalui simbol anak panah menjelaskan bahawa fungsinya sebagai benda yang melengkapkan maksud ayat telah menonjolkan makna elemen ranah OBJEK.

Seterusnya, konsep unit-unit leksis ditandai oleh bulatan kecil berwarna coklat yang berada dalam satu lingkaran besar yang berwarna biru seperti dalam rajah. Bulatan biru tersebut mewakili elemen-elemen ranah, iaitu elemen ranah SUBJEK, elemen ranah PERKARA GHAIB dan elemen ranah OBJEK. Setiap elemen ranah tersebut pula saling berhubungan antara satu dengan yang lain, ditandai oleh simbol anak panah untuk menerbitkan elemen ranah KEPERCAYAAN yang digambarkan dengan satu bulatan besar berwarna merah. Anak panah terputus-putus pula menunjukkan bahawa rangkaian setiap konsep unit leksikal dalam bentuk struktur ayat menyerlahkan lagi elemen ranah tersebut. Leksis singkowoton yang merupakan fokus kajian menunjukkan hubungan secara langsung beberapa leksis yang bergandingan bersamasamanya. Selanjutnya, perkaitan antara unit leksis sebagai peranti semantik yang menerbitkan elemen-elemen ranah SUBJEK, PERKARA GHAIB dan OBJEK telah berjaya menyerlahkan elemen ranah KEPERCAYAAN. 


\section{Kesimpulan}

Mekanisme yang sistematik dengan menggunakan teori lingustik berjaya memerihalkan fenomena dan gelagat leksis bahasa sukuan dalam korpus bahasa Melayu. Berdasarkan analisis dan perbincangan yang dikemukakan, khususnya tentang leksis bahasa sukuan singkowoton, berjaya membuktikan bahawa kewujudan leksis tersebut bukan secara sewenang-wenangnya tetapi boleh dijelaskan secara sistematis dengan menggunakan pendekatan semantik ranah. Perbincangan tentang leksis bahasa sukuan dalam korpus bahasa Melayu dapat diperinci dengan melibatkan aspek leksikal, sosiobudaya dan pemikiran masyarakat penuturnya.

\section{Rujukan}

Abdul Hakim Mohamad. (2014). Spiritual Journey of Murut Tahol in Sabah and Its Effect to their Headhunting Practice. International Journal of Social Science and Humanity, Vol 4, No 6, Nov 2014. hlm 426-429.

Abdullah Hassan. (2009). Bahasa Melayu di Persimpangan: Antara Jati Diri dengan Rempuhan Globalisasi. Dlm Kemanusiaan 16 (2009) 59-81.

Aini Hj Karim. (2005). Teori medan makna pendeskripsian leksikal kata kerja dalam Bahasa Melayu. Jurnal Bahasa. Jilid 5 Bil 3 Septmber 2005, hlm 78-104.

Amil Jaya. (1979). Bagaton. Kuala Lumpur. Dewan Bahasa dan Pustaka.

Amil Jaya. (2012). Mariga. Kuala Lumpur. Dewan Bahasa dan Pustaka.

Anida Saruddin. (2011). Peluasan makna kata serapan bahasa Arab: Analisis semantik kognitif. Tesis Doktor Falsafah. Bangi: Universiti Kebangsaan Malaysia.

Asimah Hj. Ajamain. (2009). Komunikasi berkesan dengan bahasa sukuan. Dlm Etnik Melestarikan Bahasa Sukuan Sabah. hlm. 9-13. Kota Kinabalu: Dewan Bahasa dan Pustaka Cawangan Sabah. 
Asmah Omar. (1994). Bahasa dan Pemikiran Alam Melayu. Kuala Lumpur. Dewan Bahasa dan Pustaka.

Atkins, B.T.S., dan Rundell, M. (2008). The Oxford guide to practical lexicography. Oxford: Oxford University Press.

Azmah Nordin. (1988). Dukanya Abadi. Kuala Lumpur. Dewan Bahasa dan Pustaka.

Azmah Nordin. (1990). Kukui. Kuala Lumpur. Dewan Bahasa dan Pustaka.

Azmah Nordin. (1992). Dari Dalam Cermin. Kuala Lumpur. Dewan Bahasa dan Pustaka.

Azmah Nordin. (1992). Debur Menerpa. Kuala Lumpur. Dewan Bahasa dan Pustaka.

Daftar Kata Bahasa Sukuan Sabah: Bahasa Melayu-Bahasa Murut Tahol. (2005). Kuala Lumpur. Dewan Bahasa dan Pustaka.

Evans. V., dan Green. M. (2006). Cognitive Linguistics An Introduction. Edinburgh. Edinburgh University Press Ltd.

Fillmore, C.J., (1982). "Frame Semantics" dlm The Linguistic Society of Korea (ed.) Linguistic in the Morning Calm. Seoul: Hanshin Publishing Co.

Fillmore, C.J., \& Petruck, M.R.L., (2003). "FrameNet Glossary" dlm. International Journal of Lexicography. 16:3, hlm 235-360.

Fillmore, C.J., \& Petruck, M.R.L., (2003). "Background to FrameNet" dlm. International Journal of Lexicography. 16:3, hlm 235-50.

Fillmore, C.J. (2006). Frame Semantics. Dlm K.Brown (pnyt). Encyclopedia of language and linguistics. Hlm 613-620. Oxford: Elsevier.

Fillmore, C.J., \& Baker, C. (2010). A frames approach to semantic analysis. Dlm Heine, Bernd dan Narrog, Heiko (pnyt). The Oxford Handbook of linguistic analysis. Hlm 313-339. Oxford: Oxford University Press. 
Fillmore, C.J., dan Baker, C. (2001). Frame Semantic for Text Understanding.

Geeraerts, D. (2010). Theories of Lexical Semantics. New York: Oxford University Press Inc.

Glosari leksikal Bahasa Sukuan. (2012). Kuala Lumpur. Dewan Bahasa dan Pustaka.

Hajar Abd. Rahim. (2005). Bahasa dan Identiti: Satu kajian tentang pengaruh leksis tempatan dalam evolusi bahasa Inggeris standard di Malaysia. Kertas Kerja Seminar Kebangsaan Kacukan Bahasa dan Bahasa Kacukan: Proses Penduduk dan Daya Hidup. USM, Pualau Pinang. 17 September.

Hasan Mat Nor (pnyt). (1998). Warga Peribumi Menghadapi Cabaran Pembangunan: Kertas Kadangkala Bil.8. Jabatan Antropologi \& Sosiologi. Universiti Kebangsaan Malaysia.

Hood Salleh. (2004). Dunia Peribumi dan Alam Sekitar Langkah ke Hadapan,. Bangi. Universiti Kebangsaan Malaysia.

Hunston, S,. (2002). Corpora in Applied Linguistics. Cambridge: Cambridge University Press.

Intan Safinaz Zainuddin. (2011). Analisis makna dan padanan dalam kamus Dwibahasa Melayu-Inggeris.

Intan Safinaz Zainuddin. (2013). Malay FrameNet: An Application for Bilingual Dictionary. PERTANIKA, Social Science and Humanities. 21 (S): 41-50 (2013) Journal homepage: http://www.petanika. upm.eu.mt/. Diakses pada 3 Nov 2014.

Intan Safiaz Zainuddin, Nor Hashimah Jalaluddin dan Imran HoAbdullah. (2012). Entri, Makna dan Padanana dalam Kamus Dwibahasa Melayu-Inggeris: Satu analisis Semantik Ranahan. Jurnal Bahasa Jilid 12 Bil 1. Jun 2012 (41-59). 
Intan Safiaz Zainuddin, Nor Hashimah Jalaluddin dan Imran HoAbdullah. (2014). Meaning in Malay-English Dictionaries: An Application of Frame Semantics and the Framenet. Kajian Malaysia, Vol. 32, Supp. 2014. 131-149.

Intan Safinaz Zainuddin dan Nor Zakiah Abdul Hamid. (2008). Tinjauan Unsur Budaya dalam Kamus Dwibahasa Melayu-Inggeris. Dlm Nor Hashimah \& Rusmadi Baharuddin (pnyt). Leksikologi dan Leksikografi Melayu: hlm 495-507. Kuala Lumpur: Dewan Bahasa dan Pustaka.

Melcuk, I. (2001). "Collocations and Lexical Functions". Dlm. Corie, A.P (ed), Phraseology. London: Oxford University Press.

Mohd. Taib Osman. (1988). Bunga Rampai Kebudayaan Melayu. Kuala Lumpur: Dewan Bahasa dan Pustaka.

Nathesan. (1994). Pertembungan budaya bahasa Melayu dengan bahasabahasa bumiputera di Sabah: Satu tinjauan dari aspek kosa katanya, Jurnal Bahasa. 38(12): 1097-1113.

Noresah Baharom (pnyt). (2013). Kamus Dewan. Kuala Lumpur. Dewan Bahasa dan Pustaka.

Nor Hasimah Jalaluddin, Anida Saruddin dan Zaharani Ahmad. (2012). Peluasan makna Alim: Analisis Semantik kognitif. Gema Online Journal of Language Studies Vol 12 (2), May: 457-473.

Nor Hasimah Jalaluddin, Zaharani Ahmad dan Anida Saruddin. (2011). Daripada "alam darjat" kepada "alam fizikal": Analisis Semantik kognitif. Jurnal Melayu (8)2011: 1-26.

Nor Hasimah Jalaluddin, Zaharani Ahmad dan Nurul Huda Mohd Saad. (2010). Peluasan makna imbuhan Ber-: Analisis Semantik kognitif. Gema Online Journal of Language Studies Vol 10 (1), May: 103123.

Norliza Jamaluddin. (2000). Perkamusan Melayu: Sumbangan Data Korpus Berkomputer. Latihan Ilmiah. Kuala Lumpur: University Malaya. 
Norsimah Mat Awal. (2003). Analisis struktur dalaman dan peluasan makna kata adjektif dari prespektif semantik kognitif: Terjemahan karya Shahnon Ahmad. Tesis PhD. Bangi: Universiti Kebangsaan Malaysia.

Norsimah Mat Awal. (2009). Peluasan makna kata "aman" dan "manis" berdasarkan data korpus. Dlm. Nor Hashimah Jalaluddin et. al Linguistik Teori \& Aplikasi. Hlm. 114-135. Bangi: Universiti Kebangsaan Malaysia.

Norsimah Mat Awal. (2002). Dari buah yang lunak ke angin yang lunak: Analisis peluasan makna kata adjektif indera. Kertas Kerja. Persidangan Linguistik ASEAN. Universiti Brunei Darussalam, Brunei, 28-30 Oktober.

Okumura M \& Siew Y.Y. (2013). An Osteological Study of Trophy Heads: Unveiling the Headhunting Practice in Borneo. International Journal of Osteoarchaeology In. J. Osteoarchaeology. 23: Hlm. 685-697.

Pedoman Umum Pembentukan Istilah Bahasa Melayu Edisi Baharu. (2004). Kuala Lumpur. Dewan Bahasa dan Pustaka.

Puteri Roslina Abd Wahid. (1994). Budaya dan nilai kepercayaan makna berdasarkan anatomi manusia.

Puteri Roslina Abdul Wahid. (2012). Menelusuri Peristilahan BM: 114: KL: Penerbit Universiti Malaya.

Raja Mukhtaruddin Raja Dain. (1971). Daya Cipta Bahasa Malaysia dalam pembentukan keperibadian kebangsaan. Kongres Kebudayaan Kebangsaan. Kuala Lumpur. Universiti Malaya. 16-20.

Rusmadi Baharuddin. (2005). Pemerian polisemi "datang": satu analisis linguistik kognitif, Jurnal Bahasa 5(4): 23-39 Disember.

Rusmadi Baharuddin. (2009). Menangani Sinonim dalam Kamus: Satu Pendekatan Semantik Ranahan. Dlm Nor Hashimah \& Rusmadi Baharuddin (pnyt). Leksikologi dan Leksikografi Melayu: hlm 372387. Kuala Lumpur: Dewan Bahasa dan Pustaka. 
Rusmadi Baharudin, Nor Hashimah Jalaluddin dan Imran Ho-Abdullah. (2013). Sumbangan Framenet kepada Leksikografi Korpus: Kajian kes Penyelisikan Makna Kata kerja Melihat.

Saidatul Nornis Hj. Mahali. (2007). Unsur Bahasa dalam Budaya. Kota Kinabalu: Penerbit Universiti Malaysia Sabah.

Saidatul Nornis dan Mohd Rasdi. (2013). Haiwan sebagai perlambangan dalam peribahasa orang Semai. GEMA Online Journal of Language Studies Vol 13(1) Feb: 83-98.

Sapir, E. 1921. Language: An Introduction to the study of speech. London: Harcout Brace Jovanovich Publishers.

Sinclair, J. (1991). Corpus, concordance, and collocation. Oxford. Oxford University Press.

Slobin, D.I. (1996). From "thought and language" to "thingking for speaking”. Dlm J.J. Gumperz, \& S.C. Levinson (pnyt). Rethingking linguistic reality. Hlm 70-96. Cambridge: University Press.

Stubbs, M., (1996). Text and Corpus Analysis. Blackwell Publishers.

Wan Abdul Kadir Wan Yusoff. (2005). Bahasa dan Pemikiran Budaya. Dlm. Hashim Hj Musa (pnyt). Bahasa dan Pemikiran Melayu; hlm. 134. Kuala Lumpur: Akademi Pengajian Melayu.

Zaitul Azma dan Ahmad Fuad. (2011). Bahasa dan Pemikiran dalam Peribahasa Melayu. GEMA Online Journal of Language Studies Vol 11(3) Sept: 31-51.

Zaleha Ahmat. (2001). Falsafah Etika Masyarakat Melayu Tradisional: Satu kajian berdasarkan pantun Melayu. Disertasi Sarjana. Kuala Lumpur: Universiti Malaya.

Zubaidi Abas. (2009). Wawasan Etnik. Kota Kinabalu. Dewan Bahasa dan Pustaka Cawangan Sabah. 6 Disember 2009. 